\title{
Phraseological Units: Persuasion and Translation
}

\author{
Marisa Díez Arroyo \\ University of Oviedo \\ arroyo@uniovi.es
}

\begin{abstract}
This paper explores the persuasive power of phraseological units (PUs) in cosmetics leaflets written either in English or French, together with their translation into French or English, respectively, as well as into Spanish.

The approach rests upon, firstly, the concept of genre, determined, in agreement with Swales (1990), on the basis of the purpose of the text. Cosmetics leaflets are argued to be a manifestation of advertising. Hence, their ultimate aim is to persuade the (potential) buyer about the benefits of the product. Secondly, the occurrence of the phraseological units in this type of genre has important consequences for rhetoric and stylistics. Thirdly, we deal with the definition of phraseological units and their relation to metaphor, which will permit us to study how persuasion is achieved through this particular text type. Finally, by comparing the source text with its translation into two other languages, we analyse whether the translator has grasped the stylistic effect of the phraseological units and has succeeded in conveying a similar value in the target language text.
\end{abstract}

\section{Introduction}

Following a steady growth of scholarly interest and activity over the last thirty years, phraseology has become a major field of pure and applied research (Cowie, 2001: 1-2). As happens to many other issues in contemporary linguistic theory, the analysis of phraseology can prove more fruitful when linked to other important phenomena. Thus, when carrying out a study of phraseological units (henceforth PUs), it is tempting to adopt a grand, overarching strategy so as to attain sweeping generalisations. On the contrary, the more fields considered, the greater the risk of increasing the number of variables unnecessarily. Bearing all this in 
mind, it was decided to circumscribe the present work to those aspects that help define and understand the persuasive features of phraseological units as employed in cosmetics leaflets. The approach is completed with a contrastive analysis of the treatment of these units and their rhetorical effect in the translated versions of these texts. In this way, the aim of this paper is twofold: firstly, to evaluate the rhetorical use of PUs in cosmetics leaflets, a type of text that is arguably a manifestation of advertising. Secondly, to contrast the source text (in English and French) with its translation into two other target languages (French and English, respectively, together with Spanish). With this double purpose we hope to contribute to a better understanding of the role of these multiword units in cosmetics leaflets, as well as to reflect upon the difficulties of translating them.

Our work presents the following overall organisation: the opening section turns to the definition of the concept of genre in terms of purpose. Then we make the case that cosmetics leaflets belong to the genre of advertising. To support this argument, we analyse the ultimate objective of advertising, followed by the characterisation and justification of our corpus. This discussion will take us to considerations about rhetoric and stylistics. We then address the question of phraseological units: the theoretical underpinnings of the terminological problem surrounding this concept and their definition. The focus of this part is to explain how PUs are employed in the genre of advertising to achieve rhetorical effects. Generally, we develop the idea that the rhetorical character of the choices made by advertising writers of cosmetics leaflets through phraseological units lies in their metaphorical power. We then formulate a working hypothesis grounded in the cognitive approach to metaphor. It should be stated that although this approach has not provided the theoretical framework of the present study, it has been used as one important source of theoretical and analytical considerations. To round off this theory-bound part of the paper, we make some observations on the translation of phraseological units. The remainder of the work is devoted to the analysis of data. We then conclude by offering some final remarks on the findings.

\section{The genre of advertising}

\subsection{The concept of genre}

The term 'genre' is often employed in interchangeable ways with that of 'rhetoric'. As Maureen (1993:9) observes, this is unexpected in view of the fact that their origins have little in common: the former has long been used in literary studies to designate different types of literary writing, while the latter originated in ancient Greece as the study and practice of eloquent and/or persuasive speech. This section and the following will discuss the concepts of genre and rhetoric in order to see how they might relate to one another.

We will begin by addressing the question of what exactly a genre is and what its defining features are. Swales (1990: 58) has defined 'genre' as follows:

A class of communicative events, the members of which share some set of communicative purposes. These purposes are recognised by the expert members of the parent discourse community, and thereby constitute the rationale for the genre. This rationale shapes the schematic 
structure of the discourse and influences and constrains choice of content and style.

This proposal, to which we adhere, presents genre as dependent on the notions of communicative event and communicative purposes. That is, Swales prioritises social purpose over structures; these, although necessary, are not crucial because the defining feature of genres is their primary, basic purposes, the communicative events themselves. More problematic is the rather narrow and restrictive role of the discourse community pointed out by Maureen (1993: 14). In her view, it is difficult to think of a constant relationship between a discourse community and the genres it is supposed to possess (thus it varies in defining, naming and regulating cinema, academic discourse or everyday encounters). This author (1993: 15) suggests instead that social groups are united by genres, helping to maintain and regulate them. In so doing, these social groupings influence the interpretation of texts in the genre.

In spite of these precisions, we understand that the most important advantage of Swales' definition and, consequently, its major contribution to the present study is the importance it gives to social purpose. This is in fact the question we should try to answer next: the purpose of advertising and how it helps to shape this particular genre.

\subsection{The function of advertising}

Advertising is so familiar to us that we do not often pause to think about its nature, taking it, most of the times, for granted. However, classifying texts is more complex than it might appear at first glance, because as soon as we try to arrive at a satisfactory answer we should bring into play important considerations about how they appear and are used (Goddard, 1998: 6).

In an effort to produce a response to the question which gives title to his article ("How is understanding an advertisement possible?"), Pateman (1983: 189) heatedly argues that the purpose of advertising is to sell products, and that without this knowledge an advertisement is not understandable. Keiko Tanaka, another scholar in the field, goes one step further. She does not fully share the claim that advertisers are to depend entirely upon their audience's recognition of their goal, emphasising instead that "the ultimate purpose of an advertiser is to change the thinking of uninterested persons in his audience and make them buy his product" (2001:9). Although not stated plainly, the verbal phrases "to change the thinking" and "make them buy" can only be equivalent to persuade.

Contrary to what it may seem, this definition is far from being unanimously agreed upon. In fact, in the early eighties Crystal and Davy (1983: 222) defended two main functions in advertising: persuading and informing. Some years later Gillian Dyer (1992: 6) categorically concluded that

It is [...] the advertiser's task to try to persuade rather than inform. It is not really surprising that advertisements are unreliable as sources of information when one considers that they come from biased or interested quarters, namely the producers of the advertised products.

In other words, the choice of one alternative (persuading) seems to inhibit consideration of the 
other (informing). To complicate things further, more recently, Cook (2003:10), approaching the issue from the addresser's point of view, can be taken to object to a position similar to the one advocated by Dyer above on the grounds that

for each stratum the intended function may be different. Though the manufacturer may seek only to persuade people to buy, the writer may seek to impress other colleagues, or realize an aesthetic aim.

Support for his attitude is sought along the following lines:

Firstly, there are advertisements which do not sell anything, but plead or warn or seek support. [...] Secondly, there are instances of other genres, such as poems or songs, which become ads by being used in a particular way (a process which may be reversible, allowing an ad to become a poem). Thirdly, even if the majority of ads have the function of persuading their addressees to buy, this is not their only function. They may also amuse, inform, misinform, worry or warn.

Among all the reasons adduced, we will give some attention to the third being the only one directly related to the point under consideration here. Although Cook admits that persuasion is a function fulfilled by advertising and a feature to be traced in most adverts, he hastily qualifies it by adding a string of other functions. Given that the precise nature of selection criteria has not been delineated, it seems reasonable to assume that all the functions mentioned bear the same relationship to one another, participating, perhaps, of the belief that goals are more a question of degree than of absolutes.

It is our contention that, while there is no denying that persuasion is not the only function that can be attributed to advertising, it is not less true that it represents advertisers' primary goal. When an advert is launched into the market, the intention behind this act is not to improve the potential addressees' knowledge of the world, to make him laugh more often or, for that matter, to make him more aware of the world problems, but rather to sell the product it is promoting. Consequently, persuasion and the rest of the functions cannot necessarily coexist at the same level.

There remains an unresolved difficulty which is vital at this point and concerns the status of cosmetics leaflets within the genre of advertising. Enclosed in the box that contains the beauty product, cosmetics leaflets are not directly accessible to the consumer, that is to say, they have not been designed as short, memorable phrases that will move to immediate action. The conditions that surround these texts are slightly different in that their perusal will be consciously effected by an addressee who has bought - or is about to buy - the beauty product and wants to know more about it. Nevertheless, we strongly believe that these factors cannot prove a hindrance to consider cosmetics leaflets examples of advertising language on their own right, because their aim is to convince the buyers that the choice they have made - or are about to make - is the best possible one. More than ever, in order to achieve such an aim, advertisers have to move their (potential) clients through language, which gives way to persuasive techniques. As we have argued, it is precisely this point that is common to all forms of commercial advertising.

Once we have explained our viewpoint with respect to the purpose of advertising and how 
cosmetics leaflets fit in within it, the following section characterises the corpus handled and its interest for the present paper.

\subsection{The corpus}

Our corpus is made up of about fifty print cosmetics leaflets of beauty products. The curiosity for such leaflets arouses from our long standing research interest in the language of advertising, together with a more recent preoccupation for phraseology and translation issues. We began a pure random collection of cosmetics leaflets, not exempted, however, from a welldisciplined systematic reading. But as our collection grew in number, an impression started gaining ground, namely, that there was a mismatch between the detailed and neatly written information that appeared in the initial text of the leaflet and the translated versions that followed it. This apparent lack of quality among the different texts was all the more striking if we took into consideration that the different cosmetics leaflets accompanying the products all belonged to highly reputed cosmetics firms known world wide. These firms spend enormous quantities of money in their advertising campaigns in order to reach a consumer who, in most cases, must be willing to pay more than a modest price for the beauty product in question. Accustomed as we are to the usual optimum efficiency of advertising, this glaring contradiction has moved us to pay close attention to the source text and to its translated versions or target texts. Comparing and contrasting them we have discovered irregularities, but also certain linguistic recurrent patterns and common features that may be worth examining. Among them two aspects have appeared most prominently: on the one hand, the rhetorical strategy of metaphor ("beauty is at war"), which will be put forward and developed in section 4.1 below; on the other hand, the phraseological units associated to it. In line with this, cosmetics leaflets abound in examples such as "your skin is under attack", "your skin is shielded", "free radicals attack", "to help prevent wrinkles", etc. It is fascinating to take up the challenge of studying the language of advertising in relation to phraseology and translation. On a first approximation, the analysis has been restricted to cosmetics leaflets (mainly of face creams) intended for a female target group We have not contemplated the study of variables such as gender, age, product price or specific repairing products (i.e. skin stains, sun care cosmetics, etc.) in order to limit and condition the results obtained, even though their interest for future research is not to be dismissed.

Regarding the language of the material under study, our cosmetics leaflets show as source language either English or French; this has been determined on the basis of the priority given to the language in each leaflet. Taking into account that it largely matched the firm's country of origin (i.e. Dior selects French, Estée Lauder English, etc.; excepting firms such as Shisheido, which systematically choose English instead of Japanese), we felt our choice to be correct. With a mind to give a broader scope to our analysis and be able to offer more varied and interesting conclusions, we decided to compare the translation of the source text into two target languages: English or French, respectively, (invariably appearing immediately after the one selected as source language) as well as Spanish, being the present paper writer's mother tongue. 
After the characterisation of the corpus, the next step is to set out our approach to the study of persuasion, that is, rhetoric.

\section{Rhetoric and Stylistics}

The preceding section has offered various arguments to prove that persuasive intentions form part of the genre-determining purpose of advertising. Yet, this claim needs to be accompanied by an indication of how to carry out such intentions, which is partly the role performed by rhetoric and stylistics. Consequently, this part of the paper studies these two concepts, their concomitances and disparities, in so far as they smoothe the way to a better understanding of how advertisers put forth a view and support and defend it.

In Ancient times, rhetoric meant the skills of eloquent speech, practised for both aesthetic and practical goals (Mayoral, 1994: 17). According to a line of thought headed by Plato, the sophists believed that a repertoire of skills in persuasive speech could win any argument, without concern for questions of truth or beauty (Maureen, 1993: 9). This standpoint earned rhetoric its bad name and has been carried over to this day: rhetoric as persuasion has been looked down on, and "mere rhetoric" is used of a message which has no substance in it, but is likely to contain ornate language. Nevertheless, it has also been pointed out (Vickers, 1998; Fahnestock, 2005) that the notion of rhetoric as ornament might be the result of a mistranslation.

Aristotle, on the other hand, had a more positive attitude towards rhetoric and wrote two major works on the topic: Poetics and The Rhetoric. Following his tradition, which values eloquence for its own sake, rhetoric has experienced a revival, understood as an analytical tool "depicting the means that people use in realising rhetorical intentions, in forming and organising a message as language" (Maureen, 1993: 19-20). It is through the texts that rhetorical intentions are expressed and the effects are produced. Therefore, rhetoric can be captured by studying texts, outstanding elements of the communicative event that are directly accessible to observation.

In agreement with Purves (1988: 9), rhetoric is "the choice of linguistic and structural aspects of discourse -chosen to produce an effect on an audience". It seeks to answer what rhetorical consequences various choices can have. In other words, it will help us understand and explain the linguistic choices the writer makes to convince the consumers that the product in question is their best possible choice.

The point now is that choice has parallelly been a central issue to the second concept that gives title to this section: stylistics. In this way, Thornborrow and Wareing (1998: 3 ) in their introductory book on literary style perceive stylistics as "the particular choices made by individuals and social groups in their use of language". To Gläser (2001: 131) style is to be understood as the selection of linguistic means made by the sender of the message (be it written or spoken) in agreement with the communicative situation. Moreover, scholars try to narrow the concept introducing variables such the optional character of the choices (Enkvist et al., 1973: 16-17); Vinay and Darbelnet, (1995: 16) or their categorisation as motivated (Verdonk, 2002) against the distinction drawn between motivated and unmotivated choices 
(Baker, 2000).

Discussion of these issues falls well beyond the scope of this paper, but for working purposes we assume, firstly, that in many respects it proves particularly difficult to make a clear cut between rhetoric and stylistics, a distinction that will consequently be ignored in the present work. Secondly, we will not be concerned with limiting the type of choice studied, drawing on the assumption that the stylistic choices a writer makes during the writing process seem heavily constrained by the type of text he is creating, that is, by the 'genre' to which it belongs. In our specific case, this implies that all have been carefully thought up, at least in what respects the source texts.

It is of interest to note, however, another aspect that relates stylistics and choice: the tendency to view style cognitively, as the reflection of the mind (Boase-Bier, 2005: 72, and references there). Understanding the effects of style on the mind involves a consideration of cognitive processes. Thus, cognitive stylistic approaches try to relate linguistic choices to cognitive structures and processes. The study of phraseological units from a cognitive perspective will bring us a step closer to a fully apprehension of the extent of this claim.

\section{Phraseological units}

\subsection{Phraseological units and metaphor}

In this section we are going to raise the question of phraseological unit, its definition and its relationship to metaphor, discussing its place and role in cosmetics leaflets.

Whenever phraseology is invoked, it is felt as an obligation to indicate that terminology in this field has always been problematic. There is no generally agreed common vocabulary and, more often than not, a single term may be used to denote different phenomena. Despite the fact that, due to its fuzziness, the concept is delicate to delimit and classify, it is widely acknowledged among researchers (Pawley and Syder, 1983; Fernando, 1996; Wray, 2002; Moon, 2003) that in language the presence of a large amount of more or less fossilised expressions indicates that the distinction between lexicalisation and productivity is in fact a matter of degree.Phraseological unit is a very general but convenient term borrowed from Gläser (2001: 125) that covers several types of multi-word units, defined as:

a lexicalised, reproducible bilexemic or polylexemic word group in common use, which has relative syntactic and semantic stability, may be idiomatised, may carry connotations, and may have an emphatic or intensifying function in a text.

A central issue in Gläser's definition is the inclusion of connotations, as well as the emphatic and intensifying function these units may have. In fact this scholar (1986: 42-46) has strongly advocated for the contribution of PUs to the expressive power of the text they are part of.

Another close association of considerable interest is that between praseological unit and metaphor, admitted and developed by different authors, among many others Moeschler (1992) and González Rey (1995) in French or Hanks (2004) in English from Pustejovsky's (1995) Generative Lexicon theory. But it has undoubtedly been Lakoff and Johnson's (1980) work 
Metaphors we Live by which best explains and develops the intended relationship. A substantial amount of research in Cognitive Linguistics over the nearly past thirty years has set to demonstrate that "metaphor is not merely a figure of speech, but is a specific mental mapping that influences a good deal of how people think, reason and imagine in everyday life" (Gibbs, 1999: 145). Although there is no denying that many things have changed during this span of time and that present understanding of the brain and the mind is radically different, Lakoff (2008:24-25) proudly points out that basic tenets from that early period have stood the test of time. In this way, to say that a metaphor is conceptual continues to mean that it arises from recurring patterns of embodied experience. Again, in Gibbs' (1999: 162) words, "our use of metaphors to structure concepts is strongly shaped by (a) how we culturally conceptualise of situations and (b) by our interactions with social /cultural artifacts around us". The social and cultural basis of Cognitive Linguistics has also been highlighted by Langacker (1997). This scholar (1997: 241) explains that for cognitivism "metaphor is characterised as a means of understanding one domain of experience in terms of another", hence most of what we say "pertains to cultural constructions or to entities whose apprehension is in some way culturally influenced".

The immediate task is to delimit how these explanations help us understand the role of PUs in cosmetics leaflets to attain persuasive effects. Our hand-collected samples do not abound with frozen examples, rather a high proportion of them appear to be rule-governed. Yet their phraseological relevance lies in the fact that they are based on the conceptual metaphors BEAUTY is GOOD and BEAUTY is at WAR. With respect to the former, the images projected by advertising provide a good opportunity to observe the ideals of the society in which the advertising is distributed as, for instance, conventional wisdom about a strong focus on youth and beauty. The literature that examines the value of beauty as something positive has found correlations between ratings of attractiveness and social competence, intelligence, integrity, and general mental health (see Baumann, 2008 and references there). It is no wonder then that beauty is presented to the addressee as a desirable goal (to acquire or to preserve) that is constantly endangered by multiple factors, hence the second conceptual metaphor. Cosmetics leaflets recreate the metaphorical language where the existing conceptual system of WAR is used with a new item, skin, initially alien to wars but fully understandable in the context and highly efficient rhetorically. A number of interesting entailments follow from such a conceptual metaphor, illustrated with some self-explanatory extracts:

1. What do wars do? Wars destroy, provoke destructions, defeat somebody/something.

(1) Soin compensateur idéal pour lutter contre les méfaits des agressions extérieures. $<$ Sisley $>$

An ideal compensating skin care product to combat the harmful effects of external stress factors.

Tratamiento compensador ideal para luchar contra la acción de las agresiones externas. 
2. Beginning and end of war. Wars begin, lasts for a period of time. Wars come to an end, stop.

(2) $[\ldots]$ a power effect that diminishes the appearance of wrinkles can be observed after only four weeks. $<$ Kanebo $>$

De plus, après seulement quatre semaines de traitement, on observe un effet très important au niveau de la diminution de l'apparence de rides.

Además, puede observarse una disminución de las arrugas tan sólo después de cuatro semanas de uso.

3. What happens to victims in a war? The victim is attacked by the enemy(ies). The victims can recover from the attack or not.

(3) Soin anti-âge pour tous ceux qui, à tout âge, souhaitent protéger leur peau des agressions que la vieillissent prématurément. $<$ Sisley $>$

An anti-aging cream designed for those who, at any age, want to protect their skin from aggressions which cause premature aging.

Tratamiento anti-edad destinado a todas las personas que, a cualquier edad, desean proteger su piel de las agresiones que envejecen la piel prematuramente.

4. Wars are also associated with finding combat zones, identifying the enemy, looking for help, protection, defence.

(4) Pour préserver la peau, Guerlain a choisi de la renforcer également face aux agressions - premier facteur de déshydratation. $<$ Guerlain $>$

Guerlain also keeps your skin looking young by protecting it against the main cause of dry-skin: external elements.

Para conservar una piel joven, Guerlain ha querido además fortalecerla, para protegerla de las agresiones, que son el primer factor de deshidratación.

(5) More resistant to dry lines and environmental threats. $<$ Clinique $>$

Peu à peu, la peau devient moins vulnérable aux rides et ridules et aux méfaits de l'environnement.

Atenúa la apariencia de las líneas de expresión.

All this knowledge is organised in cosmetics leaflets around a two-step process: initially, the consumer is alerted about all the dangers around her skin. It is an aggressive stage that appears under the form of an attack. The metaphor chosen aims at rendering the woman aware of the dangers that surround her skin, even though some of them may lie hidden. The second phase of the persuading process tries to move the recipient of the message to action: once the woman is on alert, she is compelled to find a solution to the situation, which obviously takes the form of an effective product (the war victim reacts to the attack). Beauty is recovered or enhanced thanks to the purchased/advertised cosmetics. 
Previously to explore in detail how these ideas are shaped in practice, there is still one more interesting point that asks for our attention: the problem of phraseological units and their translation.

\subsection{Phraseological units and translation}

Running parallel to the difficulty of its definition, the translation of phraseology is certainly another thorny aspect. Within the context of the present discussion, it seems clear that part of the problem must be put down to the lack of equivalence between a PU in the source text (ST) and the target language (TL), as thoroughly discussed by Gläser (1984) or Valero Garcés (2000). But other experts in the field (Corpas, 1996; Roberts, 1998) also attribute unfortunate results in translations to the random coverage of PUs in monolingual and bilingual dictionaries, which are then of little help to professionals. The translators' training is a further cause for concern. In some cases, translators utterly fail to identify these units, a kind of behaviour that seems to point at the translator's poor command of the language in question (Corpas, 2001) or at a lack of sensibility towards PUs (Nida and Taber, 1969:99-112; Lozano, 1992: 145).

In tune with this, Boase-Bier (2006: 3) worries about the stylistic quality of translated texts, arguing that knowledge of stylistic translation theory can have a considerable impact on a translator's stylistic choices. This scholar reasons that knowing about theories involves creative engagement with them in such a way that they broaden the translator's mind, increase awareness and can free the translator from too timid a dependence on the source text. As regards metaphor and its translation in non-literary texts, Boase-Bier (2006: 100) thinks that the secondary importance attached to metre or repetitions in them invites the translator to preserve the metaphors of the ST, "and so the risk of losing an important conceptual metaphor is negligible".

As for the strategies involved in the translation of a phraseological unit from the source text into the target text (TT), Baker (1992: 72-78) suggests five different procedures:

1. Using a PU of similar meaning and form. This author admits that this strategy can only occasionally be achieved because it is very demanding: it involves using a PU in the target language which conveys roughly the same meaning as that of the source language and, in addition, consists of equivalent lexical items.

2. Using a PU of similar meaning but dissimilar form. In this case the meaning is kept but the expression in the target language consists of different lexical items.

3. Translation by paraphrase. Since it is not always possible to find a match in the target language for the PU, this seems by far the most common way of translating phraseology.

4. Omission. The PU is omitted altogether in the TT (target text) because it has no close correspondence in the target language, its meaning cannot be easily paraphrased or stylistic reasons advise against it.

5. Compensation. It implies omission of the PU at the point where it occurs in the ST so as to introduce it elsewhere in the target text.

It can be concluded that the acceptability or non-acceptability of using any of the tactics just 
described will depend upon the context in which a given PU is translated, as well as upon stylistic questions. In the analysis of the examples that follow, we will examine which of these strategies is most commonly employed and why.

\section{The analysis}

A considerable amount, if not all, of the cosmetics leaflets collected open up with what we called in section 4.1 "stage one", that is, drawing an alarming picture of the dangers that surround our skin. It is in this way that the noun phrase "skin / peau (in French)" becomes a nearly obligatory constituent of many expressions, to the extent that it can arguably be considered part of them. This happens in (6) and (7) below where the phraseological units "cause damage to" and "be under attack" appear to have the otherwise unexpected constituent "skin". The presence of this 'new' element is supposed to bring uncertainty and uneasiness. Please, note that the underlining indicates the forms under study:

(6) Free radicals are tiny oxidising molecules that can cause damage to your skin. $<$ Estée Lauder>

Les radicaux libres sont de micro-molécules oxydantes qui peuvent abîmer votre peau.

Los radicales libres poseen pequeñas moléculas oxidantes que pueden causar daños a su piel.

(7) ...all day, every day, your skin is under attack. $<$ Estée Lauder $>$

Chaque jour, tout au long de la journée, notre peau est constamment agressée. ...durante todo el día, cada día, su piel es atacada por agentes externos.

The translation strategy adopted in (6) for the target texts in French and Spanish is the one labelled "a" in section 4.2 above, namely, the one that responds to the pattern of complete equivalence in meaning and form. These versions maintain the stylistic effects that have been created in the source text. It is worth mentioning, though, that in the case of the Spanish text the alternative option "dañar su piel" ('cause damage to your skin') would have sounded more natural than the literal translation chosen.

The French target text in (7) includes the adverbial form "constamment" ("constantly') in order to reinforce the temporal dimension of the attack: "chaque jour" ("every day"), "tout au long de la journée" ("all day"). Note that the order of the time references has been inverted with respect to the source text. The Spanish TT states the attackers in the form of the prepositional phrase "por agentes externos" ('by external agents') in an effort to round off the sentence and, above all, to complete the argument structure of the passive verb "atacar" ('attack').

We turn now to an example which makes use of the PU "to wreak havoc on" so as to evoke a powerful, alarming image of the devastation that can be caused on our skin:

(8) ...the sun's UV rays can wreak havoc on skin's appearance. $<$ Estée Lauder $>$ 
...le danger des rayons UV et ses conséquences néfastes sur la peau.

Los rayos UV pueden causar estragos sobre el aspecto de su piel.

The Spanish target text uses the PU that translates exactly the meaning of the English unit, thus preserving the stylistic effects of the source text. On the contrary, the French translation has rejected the PU "infliger des dégâts" in favour of a noun ("danger", English 'danger') plus the noun and adjective sequence ("conséquences néfastes", 'harmful consequences'), a solution that, in our opinion, is not so evocative.

Let's turn to the following case:

(9) Teint brouillé, peau terne, déshydratée et sans éclat, par moments, notre rhythme de vie marque trop notre visage, la peau ne se récupère plus. $<$ Vichy $>$

A dull complexion, dehydrated and lifeless skin. Sometimes our lifestyle affects our skin too much and it is difficult for it to recover.

Cutis opaco, piel apagada, deshidratada y sin brillo. En ocasiones nuestro ritmo de vida marca demasiado nuestro rostro, la piel ya no se recupera.

The French text begins piling up expressions that collocate with "peau" ('skin') to convey the feeling of fatality that seems to lie in store for it, only to end with a PU to point at the terrible consequence of all this damage: "la peau ne se récupère plus" ("your skin cannot get over it'). In our opinion, the English target text is not so stylistically effective. Firstly, because by conflating the French adjectives "brouille" and "terne" into "dull", the cumulative effect disappears. Secondly, because the translated form "it is difficult for it to recover" is less impressive than the French original turn, in that it fails to convey the no-win situation reached by our skin. On the contrary, the Spanish TT does maintain the stylistic connotations coming from the last PU in the source text, partly due to the fact that the same expression is found in the two Latin languages. As for the string of adjectives, the original number is maintained, which guarantees the stylistic effect derived from it.

The following set of examples, headed again by French, beautifully exemplifies our rhetorical claim about the war metaphor in cosmetics leaflets:

(10) Profondément destructeurs des atouts de la jeunesse, les aléas de la vie quotidienne (surmenage, tabac, stress, manque de sommeil, pollution, fatigue, rayons UV...) attaquent en première ligne la peau fine et mobile du contour de l'œil, particulièrement vulnérable. $<$ Christian Dior $>$

The stresses and strains of daily life (overwork, smoking, stress, lack of sleep, pollution, fatigue, UV rays, etc.) are highly destructive to the physical assets of youth, and the fine, mobile skin of the eye area is especially vulnerable to attack. Profundamente destructores de la juventud, el ritmo de nuestra vida cotidiana (agotamiento, tabaco, estrés, falta de sueño, polución, fatiga, rayos UV ...) atacan en primera línea la piel fina e inestable del contorno de los ojos, particularmente vulnerable. 
The stylistic effects derived from the ST combine explicitly the two conceptual metaphors aforementioned: BEAUTY is GOOD and BEAUTY is at WAR. The first one is realised thanks to the PU "des atouts de la jeunesse" ('the assets of youth'). In the second, the source domain 'war' is related to the target domain 'beauty' in two stages: firstly, by two parallel syntactic combinations of PUs in the form of adjective phrases ("profondément destructeurs" ('highly destructive') and "particulièrement vulnérable" ('especially vulnerable') where the strength of the attacker contrasts with the victim's helplessness. Moreover, the vicinity of the former, "vie quotidienne" ('daily life'), makes the attack appear even more menacing. Secondly, the PU "attaquent en première ligne la peau" ('attack from the front/ first line the skin'), introduces a war term with the alien complement "la peau" ('the skin'), which conveys an impression of complete destruction.

The English TT starts with "the stresses and strains of daily life", a successful translation of "les aléas de la vie quotidienne" ('the hazards of daily life'), and maintains the two syntactically parallel PUs ("highly destructive" and "especially vulnerable"). Nevertheless, the change of word order misses the impact of the destruction, an effect achieved in the source text by virtue of the topicalisation effected upon the first of these PUs. With respect to the PU "attaquent en première ligne" ('attack from the front/ first line'), the English version omits it, adopting instead the compensation strategy in translation, joining the victim of the attack (i.e. the eye contour skin) to its vulnerable condition, thus rendering "is especially vulnerable to attack". A decision that is not as striking as the PU.

As far as the Spanish text is concerned, it roughly reproduces the phraseological units of the source together with its lexical arrangement, and hence, most of the stylistic effects that derived from them. The PU "atacan en primera linea" ('attack from the first/ front line') is a perfect equivalent of the French expression; the same is true of the two structural parallelisms "profundamente destructores" and "particularmente vulnerable". However, contrary to the English counterpart, the decision to translate "les aléas de la vie quotidienne" as "el ritmo de nuestra vida cotidiana" ('the rhythm of our daily life'), misses the point because the item "ritmo" ('rhythm') is far from the idea of danger meant by "aléas" ('hazards'). But all in all, in spite of the lack of subject-verb agreement ("atacan" for "ataca"), the stylistic effects are largely preserved.

As a rhetorical characteristic in the writing of cosmetics leaflets, after the initial alarming phase, a second major step consists in comforting the addressee offering the solution in the form of the advertised product or its advantages. We are going to see how this is achieved. The PU of the next English extract, which appears underlined, gives way to interesting target texts thanks to intelligent translations:

(11) ...healthy skin needs moisture. $<$ Estée Lauder $>$

...une peau bien hydratée est une peau "en bonne santé".

...una piel bien hidratada es una piel sana.

Both the French and Spanish versions have introduced the following changes: a) the verb "is" ("est", "es") for "needs"; b) the placement of the PU underlined in complement position instead of the subject position assigned to it in the source text; c) the creation of a parallel 
structure in subject position repeating lexical material ("une peau"/ "una piel", 'a skin') followed by an adjective whose ending rhymes with the ending of the PU (in " $e$ " in French and in assonant " $a-a$ " in Spanish). The back-translations would read: "A well moisturised skin is a healthy skin". All of these decisions have strengthened the stylistic effect of the phraseological unit, giving life to a more poetic text. Moreover, note that the French translation of "healthy" ("en bonne sante") appears between inverted commas, since its meaning "having a sound body and mind" is to be taken figuratively. Its perhaps more accurate equivalent "saine", however, would have spoilt the rhyme scheme. Finally, given the close similitude between the French and Spanish texts, there exits the suspicion that one used the other as source text.

The interest of example (12) lies in the linguistic innovation represented by the expression "environmental stress", a step forward that does not receive the warmest of welcomes:

(12) helps offset signs of environmental stress. $<$ Shisheido $>$

... aide à effacer les signes de stress.

... ayuda a compensar las señales del estrés del día.

While the French version simply ignores the adjective "environmental", thus losing the stylistic effects of informality arisen by the new combination, the Spanish target text goes completely off the rails. Inexplicably, the verb "offset" has been translated by "compensar" ('balance'); in addition, the word "signs" is translated by "señales", instead of the more adequate terms "marcas / signos". To cap it all, the phrase "estrés del día" ('stress of the day' sic) unsuccessfully attempts to account for "environmental stress". An unfortunate choice that would have been otherwise convincingly solved by "estrés medioambiental" ("environmental stress'), in keeping with the stylistic effects of the source text.

Consider another example below:

(13) Clarins leur [vos lèvres] donnera en plus la douceur, le confort et le soin dont elles ont besoin. $<$ Clarins $>$

Clarins offers your lips the care they need to remain soft and comfortable.

Clarins le ofrecerá además la suavidad y el bienestar que [sus labios] necesitan.

The French source text contains three nouns "la douceur, le confort et le soin" ("the softness, comfort and care') followed by the PU "ont besoin" ('have need') in such a way that the trade mark, "Clarins", the last noun ("soin") and the last element of the PU ("besoin") rhyme in nasal/e/. The stylistic effects that derive from both the rhyming and the accumulation of nouns are treated differently in the two target texts. Although the English translation has transformed the succession of nouns into a structure where two of them have become adjectives ("soft and comfortable"), thus destroying the cumulative effect, it is able to create internal rhyming, in English /i/, among three items: the trade mark "Clarins", the noun "lips" and the verb "need". The resulting Spanish target text offers no interest. It does not make any deliberate attempt to elicit any of the stylistic effects present in the source, even omitting the noun "soin" ('care') in the noun string. 
Let us turn now to the following extract:

(14) Daywear Plus guards against this damage with a unique, skin-friendly UVA/UVB screen. $<$ Estée Lauder $>$

DayWear Plus est un puissant bouclier SPF 15/30 anti-UVA/UVB.

DayWear Plus se defiende de estos daños con una exclusiva pantalla contra los rayos UVA/UVB.

The source text recovers the idea of danger by means of the items "guards against", "this damage" and "screen", presenting the product as the optimal solution that works effectively but softly ("skin-friendly screen"). Unfortunately all these rhetorical effects are lost in the two TTs. In the French text, the decision to translate the PU "guards against" by the adjective "puissant" ("powerful'), together with the omission of "skin-friendly", has the undesirable effect of reinforcing the power of the remedy in detriment of its gentleness, features so nicely conveyed in the source. The Spanish version is not much better. The translation of the PU as "se defiende" ("defends itself") distorts its meaning, since the reflexive use of the verb implies that it is the product - not the skin -that is defended from the damage, thus yielding the backtranslation "DayWear Plus is defended from this damage by an exclusive screen against UVA/UVB rays". As can be appreciated the sequence "skin-friendly" is ignored altogether.

\section{Concluding remarks}

The present study was designed to evaluate how the language of cosmetics leaflets serves the purpose of advertising, namely, to persuade the consumer. In order to show how this can be accomplished, firstly we adopted a definition of genre that emphasised the notion of communicative purpose. Then we tried to demonstrate how cosmetics leaflets are a manifestation of advertising and, hence, are largely guided by linguistic persuasive mechanisms whose ultimate aim is to move the buyer to action. In our particular case, such persuasive mechanisms derive from the use of phraseological units; these range from frozen sets to linguistic innovations, without forgetting rule-governed examples, but the feature common to all of them is that they are based on two cognitive metaphors: BEAUTY is at WAR and BEAUTY is GOOD. They rhetorically operate on two stages: the initial purpose is to bring alarm about the state of our skin. Thus the source domain, WAR, provides the notions of attack, siege, devastation, etc., that will be carried over to the target domain, BEAUTY, the victim of the fight that needs to be protected against the enemy under the form of age, pollution, atmospheric conditions and so on and so forth. Recovering our natural beauty or even enhancing it is the second step of the persuasive chain in which cosmetics leaflets are engaged, that is, the pursuit of the excellences of the product.

Our choice of study, cosmetics leaflets, is also interesting in one important respect: they offer the possibility to compare and contrast the findings relative to the source text with what happens in the other target texts included in the leaflet. The analysis of the examples originally written in either English or French has let us confirm that the use of phraseological units fulfils 
an interesting rhetorical function, consequence of a carefully thought up strategy. We have tried to go still further and examine whether this situation is parallelled in the target texts translated into French or English as well as into Spanish.

Within the context of present results, it seems clear that the TTs have behaved unevenly with respect to the stylistic effects created in the source texts. While it is obvious that in some cases there has been a conscious effort to keep the original stylistic effects, adapting the source PUs to the target language, at other times the translations appear to be completely oblivious of such effects. It has been noted, however, that the French and English target texts take more care than the corresponding translations into Spanish, comparatively weaker both stylistically and lexically.

Although it would be desirable to confirm these conclusions against a wider corpus, as well as against a larger range of target languages, it does seem reasonable to view them as having some significance. While cosmetic firms seem to go to great lengths about the creation of the source text, they should be more concerned about the quality of its translated versions.

\section{References}

Baker, Mona (1992): In Other Words. A Coursebook on Translation. London: Routledge. . (2000): "Towards a methodology for investigating the style of a literary translator". Target $12(2): 241-266$.

Baumann, Shyon (2008): "The moral underpinnings of beauty: a meaning-based explanation for light and dark complexions in advertising". Poetics 36(1): 2-23.

Boase-Bier, Jean (2005): Stylistic Approaches to Translation. Manchester: St. Jerome.

Cook, Guy (2003[2001]): The Discourse of Advertising. Second edition. London: Routledge.

Corpas, Gloria (1996): "La fraseología en los diccionarios bilingües". In M. Alvar Ezquerra, ed., Estudios de historia de la lexicografía del español. Málaga: Servicio de Publicaciones de la Universidad de Málaga, 167-182.

. (2000): "Acerca de la (in)traductibilidad de la fraseología”. In G. Corpas Pastor, ed., Las lenguas de Europa: estudios defraseología, fraseografía y traducción. Granada: Comares, 483522.

. (2001): “La traducción de las unidades fraseológicas: técnicas y estrategias”. In I. de la Cruz, C. Santamaría, C. Tejedor and C. Valero, eds., La lingüística aplicada a finales del siglo XX. Ensayos y propuestas. Alcalá: Universidad de Alcalá, 779-787.

Cowie, Anthony (2001[1998]): “Introduction”. In A. Cowie, ed., Phraseology. Theory, Analysis and Applications. Oxford: Oxford University Press, 1-20.

Crystal, David and Derek Davy (1983): Investigating English Style. Harlow: Longman.

Dyer, Gillian (1992[1988]): Advertising as Communication. London: Methuen.

Enkvist, Nils, John Spencer and Michael Gregory (1973): Linguistics and Style. London: Oxford University Press.

Fahnestock, Jeanne (2005): "Rhetorical stylistics". Language and Literature 14(3): 215-230.

Fernando, Chitra (1996): Idioms and Idiomaticity. Oxford: Oxford University Press.

Gibbs, Raymond (1999): "Taking metaphor out of our heads and putting it into the cultural world". In R. Gibbs and S. Gerard, eds., Metaphor in Cognitive Linguistics. Amsterdam: John Benjamins, 145-166.

Gläser, Rosemarie (1984): “The translation aspect of phraseological units in English and German”. 
Papers and Studies in Contrastive Linguistics 18: 123-134.

. (2001[1998]): "The stylistic potential of phraseological units in the light of genre analysis". In A. Cowie, ed., Phraseology. Theory, Analysis and Applications. Oxford: Oxford University Press, $125-143$.

Goddard, Angela (1998): The Language of Advertising. London: Routledge.

González Rey, Maribel (1995): "Le rôle de la métaphore dans la formation des expressions idiomatiques". Paremia 4: 157-167.

Hanks, Patrick (2004): “The syntagmatics of metaphor and idiom". International Journal of Lexicography 17(3): 245-273.

Lakoff, George (2008): “The neural theory of metaphor". In R. Gibbs, ed., The Cambridge Handbook of Metaphor and Thought. Cambridge: Cambridge University Press, 17-38.

Lakoff, George and Mark Johnson (1980): Metaphors we Live by. Chicago: University of Chicago Press.

Langacker, Ronald (1997): "The contextual basis of cognitive semantics". In J. Nuyts and E. Pederson, eds., Language and Conceptualization. Cambridge: Cambridge University Press, 229-252.

Lozano, Carlos (1992): “Aproximación al problema de las expresiones idiomáticas y su traducción”. Sendebar 3: 141-156.

Maureen, Anna (1993): Cultural Differences in Academic Rhetoric. Frankfurt: Peter Lang.

Mayoral, José Antonio (1994): Figuras retóricas. Madrid: Síntesis.

Moeschler, Jacques (1992): “Métaphores et idiomes: compositionalité, interprétabilité et inférence". In J. E. Tyvaert, ed., Lexique et Inférences. Paris: Klincksieck, 97-114.

Moon, Rosamund (2003[1998]): Fixed Expressions and Idioms in English. A Corpus-Based Approach. Oxford: Clarendon.

Nida, Eugene and Charles Taber (1969): The Theory and Practice of Translation. Leiden: Brill.

Pateman, Trevor (1983): "How is understanding an advertisement possible?" In H. Davis and P. Walton, eds., Language, Image, Media. Oxford: Blackwell, 187-204.

Pawley, Andrew and Frances Syder (1983): "Two puzzles for linguistic theory: nativelike selection and nativelike fluency". In J. Richards and R. Schmidt, eds., Language and Communication. London: Longman, 191-225.

Purves, Alan (1988): "Introduction". In A. Purves, ed., Writing across Languages and Cultures. Newbury Park: Sage, 9-21.

Pustejovsky, James (1995): The Generative Lexicon. Cambridge, Massachusetts: MIT Press.

Roberts, Roda (1998): “Phraseology and translation”. In P. Fernández Nistal and J. M. Bravo Gozalo, eds., La traducción: orientaciones lingüisticas y culturales. Valladolid: Servicio de Publicaciones de la Universidad, 61-77.

Swales, John (1990): Genre Analysis. English in Academic and Research Settings. Cambridge: Cambridge University Press.

Tanaka, Keiko (2001[1994]): Advertising Language. A Pragmatic Approach to Advertisements in Britain and Japan. London: Routledge.

Thornborrow, Joanna and Shân Wareing (1998): Patterns in Language: An Introduction to Language and Literary Style. London: Routledge.

Valero Garcés, Carmen (2000): "El estereotipo en la comunicación: uso y traducción de fórmulas rutinarias en inglés y en español”. In G. Corpas Pastor, ed., Las lenguas de Europa: estudios de fraseología, fraseografía y traducción. Granada: Comares, 455-482.

Verdonk, Peter (2002): Stylistics. Oxford: Oxford University Press.

Vickers, Brian (1998): In Defence of Rhetoric. Oxford: Clarendon Press.

Vinay, Jean-Paul and Jean Darbelnet (1995): Comparative Studies of French and English: A 
Methodology for Translation. Amsterdam: Benjamins.

Wray, Allison (2002): Formulaic Language and the Lexicon. Cambridge: Cambridge University Press. 